\title{
POETICAL PATTERNS IN NICHITA STǍNESCU'S POEMS
}

\author{
ALINA ROINIŢĀ \\ Faculty of Letters, University of Bucharest, \\ Strada Edgar Quinet, numărul 5-7, sector 1, \\ postal code 010017 . \\ E-mail address: alina.roinita@yahoo.com
}

\begin{abstract}
Motto:
„Poetry is a semantic force to a word which does not exist, that it was not found. The poet creates semantics of a word that does not exist. Semantics precedes the word."
\end{abstract}

(Nichita Stănescu, The Physiology of poetry)

\begin{abstract}
Through our study we have established a potential pattern of analysis over the aspect of poetical language. The theme was determined by the purpose of implementing the particular linguistic model created by N. Stănescu, which we call the nichitastănescu pattern. We exemplified the model by identifying the compositional values and the structures that contribute to the creation of a linguistic frame built to measure the main semantics, through which the poetical language is internalized and aestheticized. We also use a specific poetical construction model based on the triadic analysis pattern proposed by the French semiotics group entitled Groupe $\mu$, in their collective work Rhétorique de la poésie: lecture linéaire, lecture tabulaire, published in 1977.

The value of this study consists in a detailed view over the textual dimensions of expressiveness and significations in the poetical language used by Nichita Stănescu. Throughout his lyrics, the named poet reveals the uniqueness of his specific poetical language in contrast with other Romanian poets.

Key words: accumulation, progression, transitive value, pattern, Nichita Stănescu, Groupe $\mu$, triadic.

\section{INTRODUCTION}

Through our study we have established a potential pattern of analysis over the aspect of poetical language. Our informational base consists of literary texts written by the Romanian poet Nichita Stănescu in which the main criteria of selection was based on two values: expressiveness and suggestion.
\end{abstract}


The selected theme was determined by the academic purpose of implementing the particular linguistic model created by N. Stănescu, which we call the nichitastănescu pattern. We exemplified the model by identifying the compositional values and the structures that contribute to the creation of the poetic text: accumulation, progression, transitive value, convergent and divergent terminology etc. All these concepts create a linguistic frame built to measure the main semantics, through which the poetical language is internalized and aestheticized in the texts of Nichita Stănescu. Over this linguistically method of structuring the poetical text, we have formed a specific poetical construction model based on the triadic analysis proposed by the French semiotics group entitled Groupe $\mu$, in their collective work Rhétorique de la poésie: lecture linéaire, lecture tabulaire, published in 1977.

The value of this study consists in a detailed view over the textual dimensions of expressiveness and significations in the poetical language used by Nichita Stănescu. This specific type of discourse is not new by its terminology, but it is innovative in the alteration of the common language, which is transformed from its initial significant value into a new art of expression. Throughout his lyrics, Nichita Stănescu reveals the uniqueness of his specific poetical language in contrast with other Romanian poets.

\section{CONVERGENCE AND DIVERGENCE RELATIONS (POETICAL EUPHORIA AND DYSPHORIA)}

In the case of Nichita Stănescu, the poetry can be seen as a break in the wall of the literary movements and time, so it goes above the poetic tendencies. The poetic state is an act of being by assuming the reality through the semantics that embody emotion. The use of the unwords syntax in divergent and convergent contexts creates unique textual accumulations, through progressions and repetitions.

In spite of the fact that the poetical form has the theoretical value of producing euphoria, however when it enters in a context of multilevel signification the contradiction between euphoria and dysphoria becomes obvious, through the convergent and divergent linguistic relation. To sum up, in a simple manner, the concept of poetical euphoria describes the positive meaning and, on the other side, dysphoria generates the negative value of the poetical signification.

The euphoric connotations are generated through the positive style used to put forward the contrast of the meanings, and poetical dysphoria is created by gradually downscaling the aesthetical value from sublime to common: "The nostrils are also an eye, an eye/ for a closer world/ the same as the eardrum, the eye $(+)$ of the blind man $(-)$, as / the silent $(-)$ tongue $(+)$ tasting/ what the eyes of the hand see only/ by embrace[...] Eye (+) in downsize (-), watching/ from outside to inside,/ and from inside to outside/ only blind (-) words $(+)$ " (Stănescu, 2009, p. 153); “With you I sleep/ I 
want only you/ charming $(+)$ whore $(-) /$ desperate $(-)$ goddess $(+)$ " (Stănescu, 2009, p. 139).

For instance, a euphoric poetical value is created by referring to the human personality, when its entity constitutes the unmatched perfection through which the laws of the universe exist (the perfect human being, the genius, the creator of words). This state of poetical perception is plausible to become untrue, therefore to involuntary embody the mediocrity because of the process of masking the defects of the human kind. The contradiction between euphoric and dysphoric appears when the inexactness of the meanings intertwines throughout metaphorical language system used by Nichita Stănescu.

\section{COMPOSITIONAL METHODS OF ORGANISING THE TEXT}

The interpretation of the literary text, from the point of view of the linguistic composition methods, offers a detailed perspective over the core structures, in which we can observe the phenomena of analogy and utopian figurative conventions. The following concepts are based on semantics and complex syntax representations.

Accumulation represents a compositional figure, which is defined by a succession of elements. The created mass of concepts has the purpose to illustrate the coinciding process between the terms of the main text and the terms of paradigm's textualization. The accumulation transforms itself in a paradigmatic metaphor and lexical density: "This is why I stumble upon things, with the temple, with the ear/ with the eardrum, with what I am/ Trying to cut off their pair,/ the shadow, a pillar to the ground" (Stănescu, 2009, p. 159). In this example, we can perceive the way in which the accumulation process comprises elements of nature and of the human being. The succession and its variables revolve around two main hemispheres: celestial and earthly, which are integrated in a unitary perspective over the primordial characteristics of the human being. Another example of the textualisation process involves the use of asyndeton; therefore the lexical structure has a more accurate expressiveness, marked by clustering the conceptual value: "sad, pale and heavy generals/ dead, gone, strayed, secular/ heavy, naked, bonny, ailing” (Stănescu, 2009, pp. 181-182).

Commutation represents a compositional figure, which is created by substituting a semantic term with another neutral one; "therefore, two terms A and B commute in C, but only if C is included in both A and B" (Dascălu, 1986, p.148). Commuting includes three terms, from which two of them transfer their meanings in the third. In the poems written by Nichita Stănescu, the commutation represents a form of language that creates new linguistic paradigms, like progression and transitive value. Examples of the commutation are: "let them give me my corpse-whole/ of the day of yesterday that is called tomorrow" ( Stănescu, 2009, pp.165-166), "Where the time can be felt,/ where the past seems to not exist,/ where the future cannot be imagined" (Stănescu, vol. I, 2005, p. 474). In the first sequence the commuting takes place by using 
the terms yesterday (A) and tomorrow (B) who transfer their linguistic value in day $(\mathrm{C})$; in the second sequence, present and future represent $\mathrm{A}$ and $\mathrm{B}$, both of them commute in the value of $\mathrm{C}$, time.

The progression is a compositional figure which consists in the process of transition, gradual or regressive, from a semantic structure to another. As a consequence, the progression is integrated in an axiomatic paradigm based on three terms; the concept was defined by Viggo Brøndal as: "positive - neutral - negative" (Dascălu, 1986, p.149). From this category, the term positive reveals the position on a scale higher than zero, while the negative one shows a scale under zero and the neutral term is constructed by the absence of the first two, staying between the limits. We can also identify three types of progression: ascending, descending and neutral; the ascending progression constructs the succession of terms in a crescendo: "Neither the sun, nor the stars, not even the moon./ Do not touch anything" (Stănescu, 2009, p. 284); "Stars, heads without bodies,/ they loved me, sliding simultaneously/ on a second as long as an hour, on an hour, as long as an year" (Stănescu, vol. I, 2005, p. 263). The descending progression structures the terms in a reversed order: "Lycurgus gives a new law/ the day after tomorrow, tomorrow, now" (Stănescu, vol. II, 2005, p. 263). The last type of progression consists in the process of neutralization, when the middle term reveals an intermediary value: "The upper jaw of the god of tomorrow/ and the lower jaw of the god of yesterday/ eating the prey of today" (Stănescu, vol. II, 2005, p. 285), "You who lay on the first snow / and yell and moan and growl..." (Stănescu, 2010, p. 338). On the most occasions, the progression can be misinterpreted as a simple enumeration, but the fundamental difference between the two concepts is given by the fact that the last compositional figure is always used with an ascending value.

The transitive value represents a compositional method through which the paradigm is constructed by "semanticalization of all the characteristics with the same naming as the intra-paradigmatic relations" (Dascălu, 1986, p. 146). The next examples reveal the mechanisms through which the transitive values are created in the poetical paradigm: "It snows with eyes of fish,/ with eyes of snakes, of dogs" (Stănescu, vol. II, 2005, p. 40); "Stars, heads without bodies,/ they loved me, sliding simultaneously/ on a second as long as an hour, on an hour, as long as an year" (Stănescu, vol. I, 2005, p. 263). The transitive value consists of two identical terms that are contextualized between another two different terms: term $\left(t_{1}\right)-$ term $\left(t_{2}\right)$ (common) term $\left(t_{3}\right)-$ term $\left(t_{4}\right)$, where $t_{2}$ and $t_{3}$ represent a relation of semantic equivalency that allows the transition. The transitional value can be easily misunderstood as progression, but the distinction between them is given only by the intermediary role that is specific to the transitional paradigm. In the process of forming the poetical language the transitivity highlights the common term as superior element inside the nichitastănescu's pattern. The interpretation of the poetical text, from the point of view of the compositional methods, allows the process of revealing the artistic construction of the figures of speech and also of the most expressive elements that can be identified at all the levels in the poetical paradigm. 


\section{THE TRIADIC POETICAL PATTERN}

Table 1: Model I for the structure of Nichita Stănescu's poetry.

\begin{tabular}{|c|c|c|}
\hline $\begin{array}{c}\text { Logos } \\
\text { (extra linguistic dialog by } \\
\text { commuting between he- } \\
\text { me) }\end{array}$ & $\begin{array}{c}\text { Anthropos } \\
\text { (the metaphysical existence, } \\
\text { the ontological contents) }\end{array}$ & $\begin{array}{c}\text { Cosmos } \\
\text { (the poetical universe: } \\
\text { elementary world, the nature) }\end{array}$ \\
\hline he stretched towards me & & $\leftarrow$ a leaf as a hand with fingers \\
\hline I stretched towards him & a hand as a leaf with teeth $\rightarrow$ & \\
\hline he stretched towards me & & $\leftarrow$ a branch as an arm \\
\hline I stretched towards him & the arm as a branch $\rightarrow$ & \\
\hline he bent towards me & & $\leftrightarrow$ the trunk as an apple \\
\hline I bent towards him & $\begin{array}{l}\text { the shoulder as a gnarled trunk } \\
\rightarrow\end{array}$ & \\
\hline I heard the quickening & & $\begin{array}{l}\leftarrow \text { of the vim beating the same } \\
\text { as blood }\end{array}$ \\
\hline he heard how it slows down & $\begin{array}{l}\text { my blood going up like the } \\
\text { vim } \rightarrow\end{array}$ & \\
\hline \multicolumn{3}{|l|}{ I passed through him $\leftrightarrow$} \\
\hline \multicolumn{3}{|l|}{ he passed through me↔ } \\
\hline I remained & & $\rightarrow$ a lonely tree \\
\hline he, & a lonely man $\leftarrow$ & \\
\hline
\end{tabular}

Source: Own research.

The triadic model, created by the $\mu$ Group (1997), represents a path to a better understanding of the literary text through semantic classes, defined by Anthropos, Cosmos, and Logos, which are organized in a triangular pattern. The poem is made not only of language, but it has, in the same time, a figurative value that requests a precise form. In the pattern that we represented above, the semantic classes are associated with two main paradigms: human being and nature. The essential relation between anthropos (human entity) and cosmos (nature) allows a figurative role-play, through a paradoxical manner in which the nature and the humanity are integrated in an interchangeable paradigm. The value of logos consists in commuting between me-him, by this dialog the entities change their elementary components substituting one with each other: "I [anthropos] remained a lonely tree", "he [cosmos], a lonely man" (Stănescu, 2009, p. 246).

Beyond the commuting process that reflects the interchangeable value, the body can be perceived as an expressive anatomy, which stays as a background in the action of forging a new world, where Nichita Stănescu illustrates, in a poetical manner, the correspondences between Human and Universe. In the chosen text the relation is constructed by contrast using the synonymy between trunk, defined as body of human and body of the tree. In this sequence, Nichita Stănescu associates the hand with a nature element: the leaf, therefore the human universe becomes a physical extension of the natural world (Stănescu, 2009, p. 246). However, in the final stage of the poem the humanity controls and shapes, from a poetic point of view, the will of the universe after its own 
plans and desires. The logical interpretation is that the human being becomes a creator of new worlds by avoiding the classical forms of speech; therefore, breaking the language barrier constructs profoundness and enchanting new rhythms.

The repetition uses a cross pattern by selecting words or collocations that create chiastic structures (G. Genette, 1978; P. Fontanier, 1977, passim). The chiasmus consists in the refinement of the lexical units from a syntactic and semantic perspective, by commuting a meaning from a phrase to another: "He stretched towards me a leaf as a hand with fingers" - "I stretched towards him a leaf with teeth"; "He stretched towards me a branch as an arm" - "I stretched towards him an arm as a branch". This sort of repetition is one of the most expressive in the poetical text because it uses two types of paradigmatic actions: transfer and inversion. In the quoted verses the chiasmus is doubled: "He stretched towards me [...] I stretched towards him", "a leaf as a hand [...] a hand as a leaf" (Stănescu, 2009, p. 246), and so on.

\section{THE PARTICULAR MODEL OF THE POETICAL CONSTRUCTION}

Table 2: Model II for the structure of Nichita Stănescu's poetry.

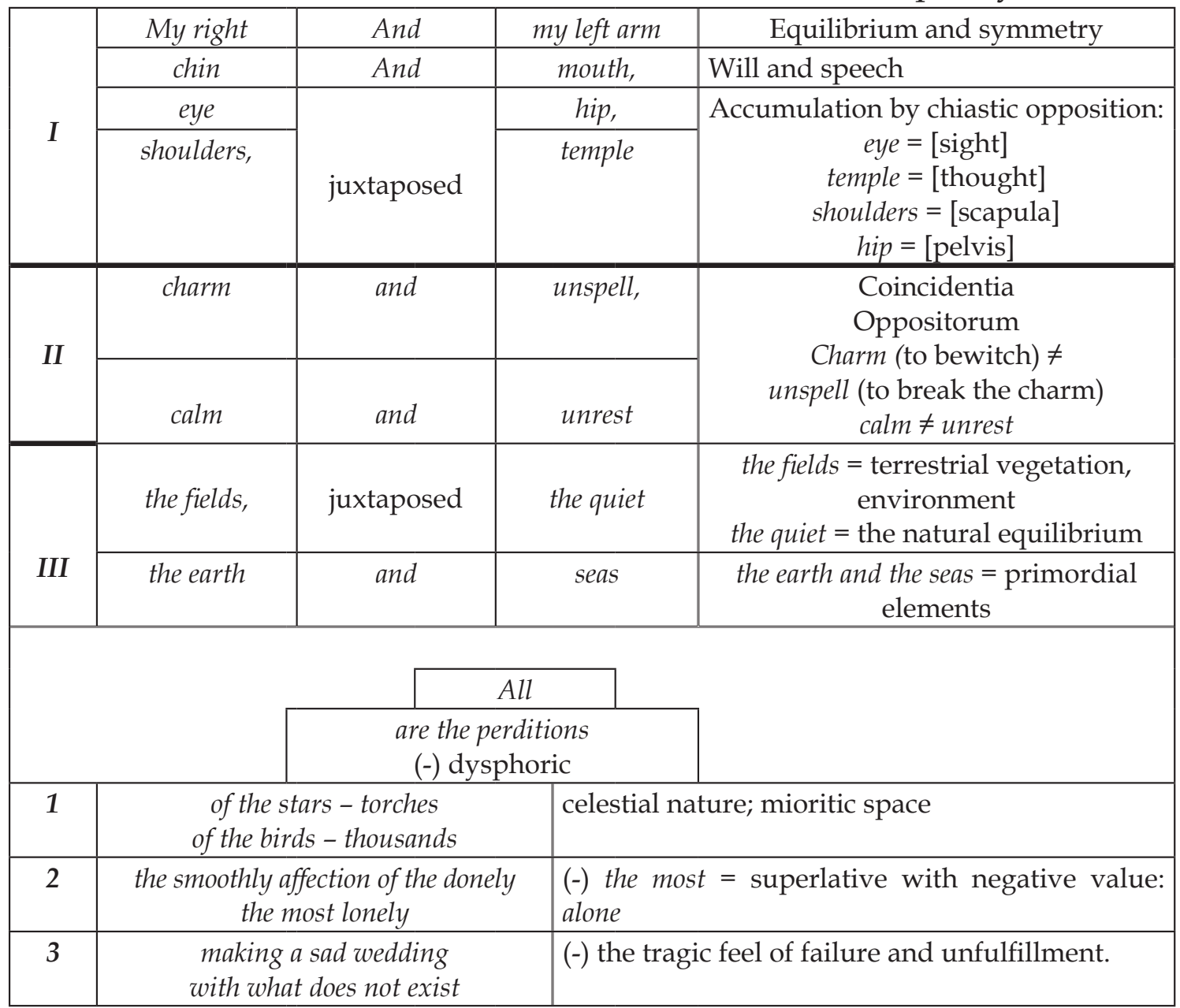

Source: Own research. 
In the poetical construction we can observe a complex language pattern in Nichita Stănescu's poems because it uses two distinct levels of prosody, initial and final, which are scaled in three categories each. In the text In the Garden of Ghetsemane (Stănescu, pp. 193-197) we can analyze this structure by regarding the word relation inside the stanza: “My right and left arm/ chin and mouth, eye/ hip, shoulders, temple/ charm and unspell,/ calm and unrest/ the fields, the quiet/ the earth and seas/ all are the perditions/of the stars - torches/ of the birds - thousands/ the smoothly affection of the donely/ the most lonely/ making a sad wedding/ with what does not exist". Although the verses are organized in a random and absurd way, they contain poetical profoundness by using the contrasts between the formed sequences and the unconventional linguistic solutions, mainly associative and dissociation, similar as in the pastoral Romanian poem Miorita (see Miorita balad, 2007, p.18). The first sequence of the initial stage is marked by using contrasts between right arm, chin, eye and shoulders and left, mouth, hip, temple. These elements represent the anatomic components of the human body that are organized through accumulations in an associative way, using the conjunction and, or dissociation, by placing a comma. "The right and the left arm", "the chin and the mouth" are elements which have the purpose to create symmetry and equilibrium, but also will and speech. The eye and the temple are constructed in a compositional figure based on opposition, therefore, their chiastic structures ( $\mu$ Group, 1997) create symbols of sight and thought, while the shoulders and the hip form together a centred bodily nature. In the second sequence of the initial prosody level we can observe the passage from the physical level to the psychical one: charm and unspell, calm and unrest, in which the contraries are put in a balance by the use of coincidentia oppositorum principle. The third sequence connotes the next two verses: "the fields, the quiet/ the earth and seas" and their transformation differs by turning from the psychical point to the terrestrial by sustaining a perpetual natural balance.

In the final paradigmatic stage the verdict is emphasized through a dysphoric meaning that opens the last triadic sequence by all are perditions. Through the verses that build the first instance: "of the stars-torches/ of the birds - thousands", it can be observed how the subtlety of the mioritic culture becomes integrated into a cosmic dimension. In the second sequence "the smoothly affection of the donely/ the most lonelier/" is revealed by the most (-) constructed as a superlative, with a negative value for the individual lost in loneliness. The last sequence transforms the individuality into a personal failure by attending at its own unfulfillment "making a sad wedding (-)/ with what does not exist (-)".

Therefore, the six moments that we have described above, from which the first three were the principal parts and the final ones were secondary, represent a perfect symmetry of the poetical language. The purpose of the dysphoric value is given by the fundamental need of the human being to interact and know the nothingness as its own limit. The human kind unveils its boundaries by contextualizing the relation between physical-psychical-terre- 
strial-cosmic. As a background, Nichita Stănescu uses poetical language that is plentiful of textual versatility, by referring to symmetries and oppositions that confer an implacable definition of his unique ars poetica.

\section{CONCLUSIONS}

From the paradigmatic analyze of Nichita Stănescu's poetical texts we can claim that the lyrical universe does not exist without art because this cultural value can be considered a supreme knowledge tool. The interpretation of the semantic structure, by processing the compositional textual methods, reveals how the triadic pattern, established by $\mu$ Group, logos, anthropos and cosmos build the poetic core.

Nichita Stănescu uses the human anatomy to build a discourse based on the fundamental principles of the poetic art. Humanity becomes a ubiquitousness entity by partitioning the bodily components in independent or integrative lexical and semiotic values of superiority. Therefore, the poetical stance covers, in the same time, the whole spectre of identity and universality. The limits between oppositions are frequently crossed through the conceptual game constructed by the poet, in which the common individual searches for its fulfillment in a universal manner, by integrating a whole external dynamic into one singular part. The consequence is an inevitable failure of the human condition, which is brought in the point of losing its own goal.

The multilevel poetical structure used is based on dissociation, symmetries and oppositions, which are structured in an innovative way by selecting a terminology that creates new concepts and surprising ideas. In this way the mundane becomes a valuable resort extraordinary. Stănescu's poetry has the ability to identify the semantic tension by posing himself between the limits, so he has the ability to create unwords, terms that do not exist in the real language, for instance, donely. The purpose of this exercise is to eliminate the boundaries around the lyrical self and to focus all the creational force in words.

Poetry is represented by a stylistic construction created through unwords, and as a consequence the language becomes limitless in the human mind. The semantic relations between the lexical structures are important because they create a context for an analyzable poetical speech based on individual and unique words. In the case of the connotative meanings of the poems, we can perceive the repetition of the compositional figures alongside the semantic structures; the combined effect enhances the dysphoric and euphoric poetical value. In the process of deconstructing the complexity of the texts "Unwords" and "In the Garden of Ghetsemane" we have shown how semantic array defines the entities of human, nature and unwords, creating the unique ars poetica of the Romanian unpaired poet Nichita Stănescu. 


\section{ANNEX A}

\section{Unwords}

"He stretched to me a hand as a leaf with fingers.

I stretched to him a hand as a leaf with teeth.

He stretched to me a branch as an arm.

I stretched to him an arm as a branch.

He bent towards me his trunk

like an apple.

I bent my shoulder

like a gnarled trunk.

I heard the quickening of his old vim beating

like blood.

He heard how it slows my blood down going up like the vim.

I passed through him.

He passed through me.

I remained a lonely tree.

$\mathrm{He}$,

a lonely man"

(Stănescu, 2009, p. 246)

\section{ANNEX B}

\section{In the Garden of Ghetsemane \\ "I.}

To search for a word which does not exist and to listen how the time becomes thicker.

A word

that you heard and suddenly

you feel it does not exist anymore...

As if you would jump out of sleep,

where they spoke in letters,

where they did not see in visions, and

they did not hear in shouts.

Oddly intertwining - the flow

of a sort of usual

into another sort of usual

and the persistence of the heart in the body

of a world

that hates the body...

II.

Mellow bond, support, presence and mouth, but especially tooth, amongst ideas.

Oh, the friendship with which you bite... 
Her name,

Without name, at its own turn,

it divides the self form itself

making it to seem and to become to himself

plentiful food...

III.

If I could be a child again, oh, God, every friend, a calf tooth it would be...

But I cannot say this any more

when the silk rope of time

bounded to the golden handle

of the gate, plucked them

all of them!...

IV.

Torn.

The ripped gum is eased only by words, not being able to bite not even

the ravenous neck - of the solar animal.

Only able to suck the sour milk

from the breast of an uneven memory.

And with all this

obstinate and sacred,

I lay over the enormous seconds

groaning cold pains, shouting

the growth of the teeth of stone.

$\mathrm{V}$.

Oh, if you would not have torn my ear,

$\mathrm{Oh}$,

if you would not have torn my eardrum

stuffed in the beastly body

of truth!

An age comes

when the truth

cannot endure witnesses anymore

I stay down in a corner

and the eardrum

I leave it to be torn apart by a secret.

An age comes when

the truth wants it all alone.

Plucked from the childhood in which

the self communicates with itself, enormous album of mine, by Moby Dick, it lets itself to be harpooned.

Friends, you - night crutches

of the Eternal lame... 
VI.

Together we have spoken along the speech of that bodies that are no longer.

we have put the livers on the table in the same time, saying to the present that it looks like the gall.

Eyebrow by eyebrow, one at a time they have left to the yesterdays.

And we have broken crystals in our fists

that were not the same with what we have today

and faded pyres we asked them

if the still have the " $u$ " vowel from the smoke...

We have transplanted the thought

slowly and uniquely in the spoken word

although the alphabet reading

was against - and the fading of the

hieroglyphs who always know

another kingdom.

The time once it is seen its not dizzy anymore

while moving the gentile bone inside the bodies.

"Is" from now on

It's a different type of "Is",

much more slower and shadier.

Because of what it is not, the jaws

are newer, more wrecked -

and another specie is for the movement

of the lonely hands, more crooked.

From one and with one and with one,

at the end it remains just one,

the one who is always present,

scared of what he is facing.

VII.

In the Garden of Ghetsemane

I come to God in my knees,

prepared for death, God,

I confess to you my dream.

I come again to you

with myself and my own

from seven with only six,

from four with only three.

Oh, the perdition has sons

and grandsons and great grandchildren

Only you can be

the eyelid closed over all of them.

My right and my left arm, 


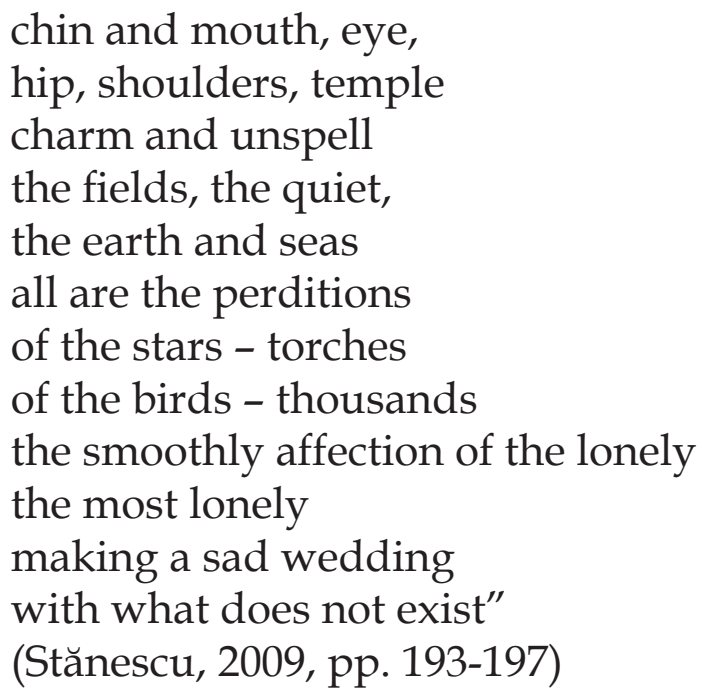

\section{REFERENCES}

[1] Stănescu, N. (2005). Opera Magna, Vol. I and II. Bucureşti: Semne.

[2] Stănescu, N.(2009). Necuvintele [Unwords]. Bucureşti: Curtea Veche.

[3] Stănescu, N. (2010). Noduri şi semne [Knots and signs]. Bucureşti: Curtea Veche.

[4] Dascălu, C. (1986). Dialectica limbajului poetic [The dialectics of the poetical language]. Timişoara: Facla.

[5] Fontanier, P. (1977). Figurile limbajului [The figures of speech]. Bucureşti: Univers.

[6] Genette, G. (1978). Figuri [Figures]. Bucureşti: Univers.

[7] Grupul $\mu$. (1974). Retorică generală [General rhetorics]. Bucureşti: Univers.

[8] Grupul ․ (1997), Retorica poeziei - lectură lineară, lectură tabulară [Poetical rhetorics - linear lecture, tabular lecture]. Bucureşti: Univers.

[9] Iordan, I. (1975). Stilistica limbii române [Stylistics of the Romanian language]. Bucureşti: Editura Ştiințifică.

[10] Miorița [The sheep]. (2007). Bucureşti: Herra. 